\title{
Decomposition of Poland's Bilateral Trade Imbalances by Value Added Content
}

\author{
tukasz Ambroziak
}

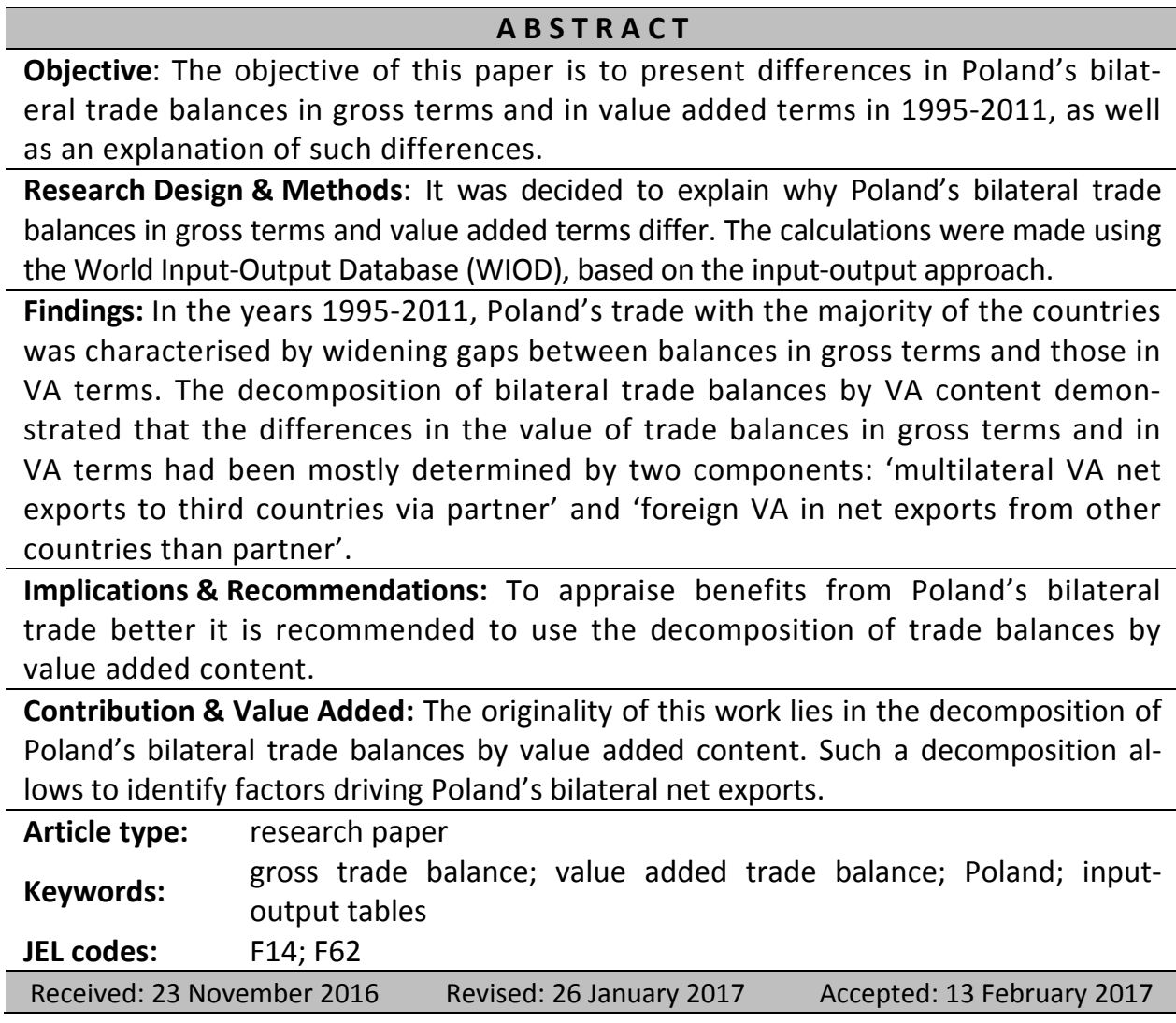

\section{Suggested citation:}

Ambroziak, Ł. (2017). Decomposition of Poland's Bilateral Trade Imbalances by Value Added Content. Entrepreneurial Business and Economics Review, 5(2), 51-69, DOI: http://dx.doi.org/10.15678/EBER.2017.050203 


\section{INTRODUCTION}

The international fragmentation of production processes, i.e. countries' specialisation in specific stages of production, and the related growth in trade in intermediate goods have become an increasingly important phenomenon since the 1980s. The development has drawn the attention of economists engaged in trade research concerning both theoretical aspects (see e.g. Grossman \& Rossi-Hansberg, 2008; Feenstra, 2010) and empirical considerations (e.g. Johnson \& Noguera, 2012; Koopman, Powers, Wang \& Wei, 2011, 2014; Stehrer \& Foster-McGragor, 2013; Timmer, Dietzenbacher, Los, Stehrer \& de Vries, 2015; Negengast \& Stehrer, 2016; Ambroziak, 2016a, 2016b). The breakthrough in the studies of the international fragmentation of production was the preparation of the world input-output tables (discussed in more detail below) and making them available. It allowed better understanding of the flows of value added (VA) content of trade between countries. Based on the world input-output tables (WIOD), it is possible to compute various indicators of individual countries' involvement in the processes of production fragmentation.

Trade statistics in VA terms take account of the contribution of particular countries to the creation of VA and eliminate the multiple calculation in the trade of components, first separately (as intermediate goods) and then as parts of final goods. Therefore, bilateral balances in gross terms (computed on the basis of traditional statistics) can markedly differ from those in VA terms (calculated on the basis of VA statistics) (Johnson \& Noguera, 2012). Thus, differences between trade balances computed in accordance with the two approaches will widen with the trading countries' engagement in global value chains. The decomposition of bilateral trade balances by value added content allows to understand better the dependence of the Polish economy on the world economy.

This paper aims (1) to present differences in Poland's bilateral trade balances in gross terms and in VA terms in 1995-2011 and (2) to explain such differences.

The analysis is based on data from the World Input-Output Database (WIOD), with the use of the input-output model. The study covered 39 trading partners of Poland and an aggregate constituting a group of countries not further specified in the WIOD.

The paper starts with the presentation of selected aspects relating to trade statistics in value added terms and the review of research studies. Next, the research method is described in detail. Further, the paper discusses the analysis results, in particular: the differences in Poland's bilateral trade balances in gross terms and in VA terms, as well as determinants explaining such differences. The paper concludes in the recapitulation of the main findings from the study conducted.

\section{LITERATURE REVIEW}

The literature distinguishes between two main concepts connected with the flow of VA between countries (Stehrer, 2013; Stehrer, 2012; Nagengast \& Stehrer, 2014). One of them, 'trade in value added', allows to determine how much of the value added created in a country is directly and indirectly embodied in the final consumption of another country. Value added may flow to the destination country directly in the form of the final product or indirectly in the form of a semi-finished product through other coun- 
tries. It means that the country concerned exports an intermediate product to a country in which it is used for the manufacture of the final product, subsequently exported to the country of destination where it is consumed or absorbed (Johnson \& Noguera, 2012). In addition to VA exports, there are also VA imports. Those allow to specify the origin of the value added absorbed in the importing country.

The concept related to VA flows between countries also enables the calculation of the value of trade balance in VA terms. Although with regard to the overall trade of a country the trade balances in gross terms and in VA terms are the same, they differ in bilateral trade. The differences arise from the exclusion from trade in value added the parts of trade flows included in traditional statistics more than once (Koopman, Wang \& Wei, 2014). Therefore, trade in intermediate goods contributes to divergent statistics according to the two concepts.

In order to demonstrate the difference between VA and gross trade balances, Figure 1 presents an example of trade between three countries. The differences between net trade in gross and VA terms result from the possibility that a country may trade with another country only indirectly via a third partner. In the example below, country A exports an intermediate worth 2 to country $B$, which then after adding some value of its own ships the final product worth 3 to $C$, where it is consumed. Thus, no physical shipment of good between $A$ and $C$ is observed, although there is value added created in country $A$, which is finally absorbed in country $C$. In this case, country $A$ runs a trade surplus with $B$ of 2 , whereas the trade between $A$ and $C$ is zero. Country $B$ runs a trade surplus with $C$ of 3 . Although country $A$ does not trade with $C$ directly, in VA terms country $A$ has a trade surplus with $C$ of 2 . In gross terms, country $A$ reports a trade surplus with $B$, whereas the trade balance in VA terms between $A$ and $B$ is zero. In VA terms country $B$ has a trade surplus with $C$ of 1 . Note that in both concepts the overall trade balances of the countries in question are the same. Country $A$ has a surplus of $2, B$ of 1 and $C$ a trade deficit of 3 .

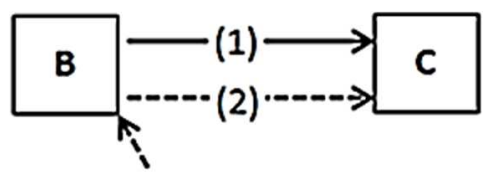

(2)

\begin{tabular}{lcc} 
& gross terms & $\begin{array}{c}\text { value added } \\
\text { terms }\end{array}$ \\
\hline trade between A and B & 2 & 0 \\
\hline trade between A and C & 0 & 2 \\
\hline trade between B and C & 3 & 1
\end{tabular}

Figure 1. Illustration of the difference between VA and gross trade balances Source: own elaboration (based on Nagengast \& Stehrer, 2014; Stehrer \& Stöllinger, 2013).

The other concept connected with value added flows between countries is 'value added in trade'. It allows to identify the origin of the value added contained in the total foreign trade of a country or in bilateral trade - between two countries. It enables the decomposition of exports of one country to another (or of the total exports of a country) by origin of the value added embodied in those exports. In this paper, the concept of 'value added in trade' is used to explain the differences in Poland's bilateral trade in 
gross and VA trade. Using a 2-country and 1-sector model Koopman et al. were the first to develop the decomposition of a country's gross exports by VA content at the bilateral level. They distinguished between the following components of bilateral exports: 1) domestic VA content of exports in the form of final goods absorbed or consumed by the direct importer, 2) domestic VA content of exports of intermediates used by the direct importer to produce final goods for the domestic market, 3) domestic VA content of exports of intermediates used by the direct importer to produce goods for export - indirect VA exports; 4) domestic VA content of exports of intermediates used by the direct importer to produce goods returned to the country of the origin of intermediate goods (reflected domestic VA); 5) foreign VA content of exports. At the same time, imports from one country to another can be decomposed into the following: 1) value added created in the country of the importer contained in both final and intermediate goods (direct VA imports), 2) re-imports - VA created in the importing country and exported to the country of the importer for its production needs, subsequently brought to the importing country, 3) VA content of the imports of a given country created in a country other than the country of the importer (Stehrer, Foster \& de Vries, 2012).

To decompose a country's bilateral gross exports, Stehrer (2013) used a method similar to that of Koopman et al. (2011). This method led to insights into the role of double counting in VA trade. However, contrary to Koopman et al. (2011), in order to develop such a decomposition of bilateral exports, Stehrer used a 3-country and 1sector model. Johnson and Noguera (2012) related VA balances to gross trade balances in terms of differences in bilateral VA to exports. However, their analysis leaves the question why these ratios differ between countries in the first place unexplained. Nagengast and Stehrer (2014) discussed two methods of the intersection between VA and gross trade flows at the bilateral level. The two methods anchor VA flows either to the country of production or to the country of final consumption, which they called the source-based and the sink-based approach, respectively. The decomposition that is most similar to the contribution of Nagengast and Stehrer (2014) is the work by Koopman et al. (2014). They 'implicitly use a variation of the source-based view when identifying VA exports in gross trade flows, but that their subdivision of VA exports is to some extent arbitrary and not based on the number of international border crossings'.

The concept of value added in trade has been rarely studied in the Polish literature. There is no publication which includes a detailed analysis of Poland's bilateral trade by value added concept. Kaliszu, Piotrowski, Błaszczuk-Zawiła and Ambroziak (2013) described the concept of value added in trade and gave some examples of it concerning both the individual products and the selected economies. Folfas (2016) compared the world and Poland's gross trade and trade in value added. Using trade statistics in value added terms Białowąs (2013) analysed the impact of the international fragmentation of production on structural changes and comparative advantage of Central European countries in international trade in various industries. In turn, Ambroziak (2015) analysed value added in trade of the four Visegrad Countries with Germany. Ambroziak (2016a) also studied Poland's bilateral trade in value added, however, the bilateral trade balances were not discussed in detail. 


\section{MATERIAL AND METHODS}

This study was carried out with the use of data from the World Input-Output Database (WIOD) containing the world input-output tables for the years 1995-2011. On the basis of the above-mentioned tables, using the input-output (IO) model, appropriate calculations were made. The basic equation is as follows (1):

$$
\mathbf{x}=\mathbf{A x}+\mathbf{f}=\mathbf{L f}
$$

where:

$\mathbf{x}$ - denotes the vector of gross output;

A - denotes the matrix of technical input-output coefficients (costs);

f - denotes the vector of final output;

$\mathbf{L}=(\mathbf{I}-\mathbf{A})^{-\mathbf{1}}$ - denotes the matrix of material-intensity (or additional demand) coefficients, also referred to as the Leontief inverse (and $\mathbf{I}$ is a unit matrix).

For the sake of a clear presentation of the essence of the calculations, the international input-output table only concerns 3 countries and one sector. The matrix notation of the equation $\mathbf{x}=\mathbf{A x}+\mathbf{f}=\mathbf{L f}$ is as follows (2):

$$
\left[\begin{array}{l}
x^{1} \\
x^{2} \\
x^{3}
\end{array}\right]=\left[\begin{array}{lll}
a^{11} & a^{12} & a^{13} \\
a^{21} & a^{22} & a^{23} \\
a^{31} & a^{32} & a^{33}
\end{array}\right]\left[\begin{array}{l}
x^{1} \\
x^{2} \\
x^{3}
\end{array}\right]+\left[\begin{array}{l}
f^{1} \\
f^{2} \\
f^{3}
\end{array}\right]=\left[\begin{array}{lll}
l^{11} & l^{12} & l^{13} \\
l^{21} & l^{22} & l^{23} \\
l^{31} & l^{32} & l^{33}
\end{array}\right]\left[\begin{array}{lllll}
f^{11} & + & f^{12} & + & f^{13} \\
f^{21} & + & f^{22} & + & f^{23} \\
f^{31} & + & f^{32} & + & f^{33}
\end{array}\right]
$$

\section{Bilateral Balance in Gross and Value Added Terms}

The VA exports between country 1 and country $2\left(\mathrm{VAX}^{12}\right)$ are defined as the value added of country 1 , which is ultimately absorbed in final demand by country 2 . $\mathrm{VAX}^{12}$ are computed in the following way (3):

$$
V A X^{12}=\left[\begin{array}{lll}
v^{1} & 0 & 0
\end{array}\right]\left[\begin{array}{lll}
l^{11} & l^{12} & l^{13} \\
l^{21} & l^{22} & l^{23} \\
l^{31} & l^{32} & l^{33}
\end{array}\right]\left[\begin{array}{l}
f^{12} \\
f^{22} \\
f^{32}
\end{array}\right]=v^{1} l^{11} f^{12}+v^{1} l^{12} f^{22}+v^{1} l^{13} f^{32}
$$

where:

$v^{i}$ - is the value added coefficient of country $i$ of the value added vector $\mathbf{v}$;

$l^{i j}$ - refers to the $i$-th row, $j$-th column element of the Leontief inverse $\mathbf{L}$;

$f^{i j}$ - denotes final goods flows from country $i$ to country $j$.

VA exports from country 1 to 2 are decomposed into three components. The first element of the last equation $\left(v^{1} l^{11} f^{12}\right)$ captures the value added directly absorbed in the partner country (final goods), which is referred to as the 'domestic VA in direct final goods exports'. The second element $\left(v^{1} l^{12} f^{22}\right)$ means the value added shipped to country 2 in intermediates which are then, after further reprocessing, consumed in country 2 , which is referred to as 'domestic VA absorbed by the direct partner'. The third element $\left(v^{1} l^{13} f^{32}\right)$ is value added which is embodied in intermediates shipped from 1 to 3 and then after further processing sent to country 2 in the form of final goods referred to as 'domestic VA 
indirectly absorbed by the direct partner' ${ }^{\prime 1}$. Stehrer $(2013$, p. 9) highlights that the route in the bilateral consideration here is from country 1 to 3 and then to country 2 .

In contrast to traditional trade statistics, trade data on the flows of goods and services from the world input-output table are characterised by the lack of differences in mirror statistics. For example, it means that the imports of country 1 from country 2 are equal to the exports of country 2 to country 1.

The calculation of the VA imports of country 1 from country 2 is based on the equation allowing to estimate the VA exports of country 2 to country 1 (4):

$$
\begin{gathered}
V A M^{12}= \\
V A X^{21}=\left[\begin{array}{lll}
0 & v^{2} & 0
\end{array}\right]\left[\begin{array}{lll}
l^{11} & l^{12} & l^{13} \\
l^{21} & l^{22} & l^{23} \\
l^{31} & l^{32} & l^{33}
\end{array}\right]\left[\begin{array}{l}
f^{11} \\
f^{21} \\
f^{31}
\end{array}\right]= \\
=v^{2} l^{21} f^{11}+v^{2} l^{22} f^{21}+v^{2} l^{23} f^{31}
\end{gathered}
$$

The first element of the last equation is the value added created in country 2 and exported as intermediate goods to country 1 where it is absorbed or consumed after further processing. The second element denotes the value added created in country 2 and shipped as final goods to country 1 . The third element is the value added created in country 2 and shipped in the form of intermediates to country 3 for its processing, subsequently sent as the final product to country 1.

Therefore, trade balance between country 1 and country 2 in VA terms can be computed according to the following formula (5):

$$
\begin{gathered}
N V A X^{12}=\left(v^{1} l^{11} f^{12}+v^{1} l^{12} f^{22}+v^{1} l^{13} f^{32}\right)- \\
-\left(v^{2} l^{21} f^{11}+v^{2} l^{22} f^{21}+v^{2} l^{23} f^{31}\right)
\end{gathered}
$$

Similarly, the gross trade balance between country 1 and $2\left(N X^{12}\right)$ can be expressed as the difference between their respective bilateral gross exports (6):

$$
N X^{12}=e^{12}-e^{21}=f^{12}+z^{12}-f^{21}-z^{21}=f^{12}+a^{12} x^{2}-f^{21}-a^{21} x^{1}
$$

where:

$e^{i j}$ - denotes gross exports from country $i$ to $j$

$z^{i j}$ - is the flow of intermediates between $i$ and $j$, which equals the share of intermediates of country $i$ in production of country $j$ ( $a^{i j}$ of the global inputoutput matrix $\mathbf{A}$ ) multiplied by the level of gross output in country $j\left(x^{j}\right)$.

\section{Decomposition of Bilateral Trade Into Value Added Components}

For the purpose of this paper, the decomposition method proposed by Stehrer (2013) was used.

Bilateral gross exports from country 1 to country 2 are a function of both demand in country 2 for final goods of country 1 and gross output of country $2, x^{2}(7)$ :

$$
e^{12}=f^{12}+z^{12}=f^{12}+a^{12} x^{2}
$$

Using the fact that the gross output of country $2, x^{2}$, is endogenous in a demanddriven Leontief system ${ }^{2}$, gross exports from country 1 to country 2 can be split into their

\footnotetext{
${ }^{1}$ The sum of this component over all trading partners (in this case $v^{1} l^{13} f^{32}+v^{1} l^{12} f^{32}$ ) is referred to in Koopman et al. (2014) as 'indirect value added exports to third countries'.

${ }^{2}$ It means that gross output can be expressed as a function of final demand in all countries in the world, $x^{2}=l^{21}\left(f^{11}+f^{12}+f^{13}\right)+l^{22}\left(f^{21}+f^{22}+f^{23}\right)+l^{23}\left(f^{31}+f^{32}+f^{33}\right)$.
} 
domestic and foreign value added part. When splitting further a country's exports into final goods and intermediate exports, this can be expressed as (8):

$$
e^{12}=\sum_{i=1}^{3} v^{i} l^{i 1} f^{12}+\sum_{i=1}^{3} v^{i} l^{i 1} z^{12}=\sum_{i=1}^{3} v^{i} l^{i 1} f^{12}+\sum_{i=1}^{3} v^{i} l^{i 1} a^{12} x^{2}
$$

Applying the property of inverse matrices (see more Koopman et al., 2014) and making some transformations (see more Stehrer, 2013 and Nagengast \& Stehrer, 2014) allow to decompose bilateral gross exports of country 1 to 2 into its VA components (9):

$$
\begin{aligned}
e^{12}= & \underbrace{v^{1} l^{11} f^{12}+v^{1} l^{12} f^{22}+v^{1} l^{13} f^{32}}_{V A X^{12}}+\underbrace{v^{1} l^{12} f^{21}+v^{1} l^{12} a^{21} x^{1}}_{D V A i M^{12}=F V A i X^{21(1)}}+ \\
& +\underbrace{v^{2} l^{21} f^{12}+v^{2} l^{21} a^{12} x^{2}}_{F V A i X^{12(2)}}+\underbrace{v^{3} l^{31} f^{12}+v^{3} l^{31} a^{12} x^{2}}_{F V A i X^{12(3)}}+ \\
& +\underbrace{v^{1} l^{12} f^{23}+v^{1} l^{12} a^{23} x^{3}}_{F V A i X^{23(1)}}-\underbrace{v^{1} l^{13} f^{32}+v^{1} l^{13} a^{32} x^{2}}_{F V A i X^{32(1)}}
\end{aligned}
$$

Using $e^{12}=f^{12}+a^{12} x^{2}$ the above equation can be also written in terms of gross exports flows as (10):

$$
\begin{aligned}
& e^{12}=\underbrace{v^{1} l^{11} f^{12}+v^{1} l^{12} f^{22}+v^{1} l^{13} f^{32}}_{(1)-(3) V A X^{12}}+\underbrace{v^{1} l^{12} e^{21}}_{(4) D V A i M^{12}=F V A i X^{21}(1)}+\underbrace{v^{2} l^{21} e^{12}}_{(5) F V A i X^{12(2)}}+ \\
& +\underbrace{v^{3} l^{31} e^{12}}_{(6) F V A i X^{12(3)}}+\underbrace{v^{1} l^{12} e^{23}}_{(7) F V A i X^{23(1)}}-\underbrace{v^{1} l^{13} e^{32}}_{(8) F V A i X^{32(1)}}
\end{aligned}
$$

The first three terms, $V A X^{12}$, comprise VA exports from country 1 to 2 , as in the equation (3).

The fourth term $\left(v^{1} l^{12} e^{21}\right)$ captures domestic VA imported by country 1 from country 2 either in the form of final goods or in the form of intermediates. These are goods produced in country 2 by already using some intermediates from country 1; therefore, exports of 1 to 2 contain value added which flows back to itself. These are referred to as 're-imports of domestic VA' or 'returned domestic VA' and denoted by DVAiM ${ }^{12}$. In the bilateral consideration this can also be interpreted as country 1's value added embodied in country 2's exports to country 1 denoted by $F V A i X^{21(1)}$, therefore $D V A i M^{12}=F V A i X^{21(1)}$.

The next two terms $\left(v^{2} l^{21} e^{12}\right.$ and $\left.v^{3} l^{31} e^{12}\right)$ capture the foreign content of country 1 's exports to country 2 , which stem from country 2 itself and other countries like country 3 . Stehrer $(2013$, p. 9) notes that that VA content of country 1 exports to 2 , i.e. FVAiX ${ }^{12(2)}$ will again pop up as country 2 re-imports of value added from country 1 when considering gross export flows from 2 to 1 .

The last but one term $\left(v^{1} l^{12} e^{23}\right)$ means that country 3 imports from country 2 either final goods or intermediates which embody value added from country 1 . These were shipped in the form of intermediates to country 2 which are taken into account by $F_{V A i X}{ }^{23(1)}$. Therefore, this is value added embodied in gross exports from country 1 to 2 which is not absorbed there but shipped further to third countries. This is domestic VA content in exports of 1 to 2 which is however not part of country 1's value added exports to country 2 .

The last term $\left(v^{1} l^{13} e^{32}, F V A i X^{32(1)}\right)$ results from exports of country 3 to 2 containing value added from country 1 . 'However, as the appearance of $l^{13}$ in these terms indicates, this results from intermediates' flows of country 1 to 3 which are not part of gross exports, i.e. physical shipment, of country 1 to 2, which are considered in this bilateral decomposition. These should already be captured by the other components discussed before and capture 'virtual VA flows' in a sense as value added is 
embodied in the consumption of country 2 which does not correspond to a physical flow of goods between these countries' (Stehrer, 2013, pp. 9-10) ${ }^{3}$.

Using the above presented method of decomposition of gross exports from country 1 to 2 , the gross exports from country 2 to 1 (gross imports of country 1 from 2) can be decomposed as (11):

$$
\begin{aligned}
& e^{21}=\underbrace{v^{2} l^{22} f^{21}+v^{2} l^{21} f^{11}+v^{2} l^{23} f^{31}}_{(1)-(3) V A X^{21}}+\underbrace{v^{2} l^{21} e^{12}}_{(4) D V A i M^{21}=F V A i X^{12(2)}}+\underbrace{v^{1} l^{12} e^{21}}_{(5) F V A i X^{21}(1)}+ \\
& +\underbrace{v^{3} l^{32} e^{21}}_{(6) F V A i X^{21(3)}}+\underbrace{v^{2} l^{21} e^{13}}_{(7) F V A i X^{13(2)}}-\underbrace{v^{2} l^{23} e^{31}}_{(8) F V A i X^{31}(2)}
\end{aligned}
$$

Thus, the gross term balance in trade between country 1 and country 2 is as follows (12):

$$
\begin{gathered}
N X^{12}=e^{12}-e^{21}= \\
=\underbrace{\left(v^{1} l^{11} f^{12}-v^{2} l^{22} f^{21}\right)+\left(v^{1} l^{12} f^{22}-v^{2} l^{21} f^{11}\right)+\left(v^{1} l^{13} f^{32}-v^{2} l^{23} f^{31}\right)}_{(1)-(3)}+ \\
+\underbrace{\left(v^{1} l^{12} e^{21}-v^{2} l^{21} e^{12}\right)}_{(5)}+\underbrace{\left(v^{2} l^{21} e^{12}-v^{1} l^{12} e^{21}\right)}_{(5)}+\underbrace{\left(v^{3} l^{31} e^{12}-v^{3} l^{32} e^{21}\right)}_{(6)}+ \\
+\underbrace{\left(v^{1} l^{12} e^{23}-v^{2} l^{21} e^{13}\right)}_{(8)}+\underbrace{\left(-v_{0}\right.}_{\left(-v^{1} l^{13} e^{32}+v^{2} l^{23} e^{31}\right)}
\end{gathered}
$$

The first three terms correspond to net VA exports with respect to final goods, intermediates, and indirect trade. The term (4) is the difference between the returned VA, whereas the term (5) reports the partner country's VA embodied in exports in net terms. It should be noted that these two terms exactly cancel out. The term (6) is the difference between VA contents from other countries in bilateral trade. Finally, the term (7) is VA exports of a country to other third countries via a direct partner, whereas the term (8) provides information on net exports which are transferred to the partner via third countries.

Poland's bilateral trade statistics in VA terms were calculated on the basis of data from the World Input-Output Database (WIOD). The database contains a set of international supply and use tables, as well as the world input-output tables by industry. The WIOD covers 40 countries, including $27 \mathrm{EU}$ Member States and 13 other major economies, such as: the USA, Canada, Brazil, Mexico, China, India, Japan, South Korea, Australia, Taiwan, Turkey, Indonesia and Russia. The database includes input-output tables for the period from 1995 to 2011 (17 years), or 35 industries by 35 industries (Timmer et al., 2015).

\section{RESULTS AND DISCUSSION}

\section{Gross Versus Value Added Balances in Poland's Bilateral Trade}

For most of the period covered (1995-2011), Poland had a negative balance in total trade in goods and services (it was the same in gross terms and in VA terms). At the turn of the 1990 s and 2000 s the deficit value was nearly $5 \%$ of Poland's GDP, at the same time accounting for over $8 \%$ of the Polish trade turnover. In the following years, as a rule, the deficit was below $2 \%$ of GDP (Figure 1). Poland enjoyed a total trade surplus in 1995, 2005 and from 2009 to 2011.

\footnotetext{
${ }^{3}$ Note that mathematically the first component of the last term in equation (9) $\left(v^{1} l^{13} e^{32}\right)$ cancels out with the respective term in country $1^{\prime}$ 's value added exports to 2 via country 3 , i.e. $v^{1} l^{13} e^{32}$. This is clear as no direct flow of goods are involved in this relation, i.e. not counted in the gross flows $e^{12}$.
} 
In 1995-2011 Poland recorded permanent deficits in gross terms in trade with countries such as Russia, China, Italy, the Netherlands, Belgium, Slovakia, Japan, South Korea and Taiwan. In the period in question there was a marked increase in the value of trade deficits with China and South Korea, and after 2004 with the United States as well. Prior to the accession to the European Union, Poland also noted negative balances in trade with the United Kingdom, France, Sweden, Spain, Turkey and the Czech Republic. However, after the accession Poland managed to develop fast-growing surpluses in trade with those countries. In the period covered surpluses were recorded in trade with Germany, Denmark, Hungary, Lithuania, Romania and Latvia.

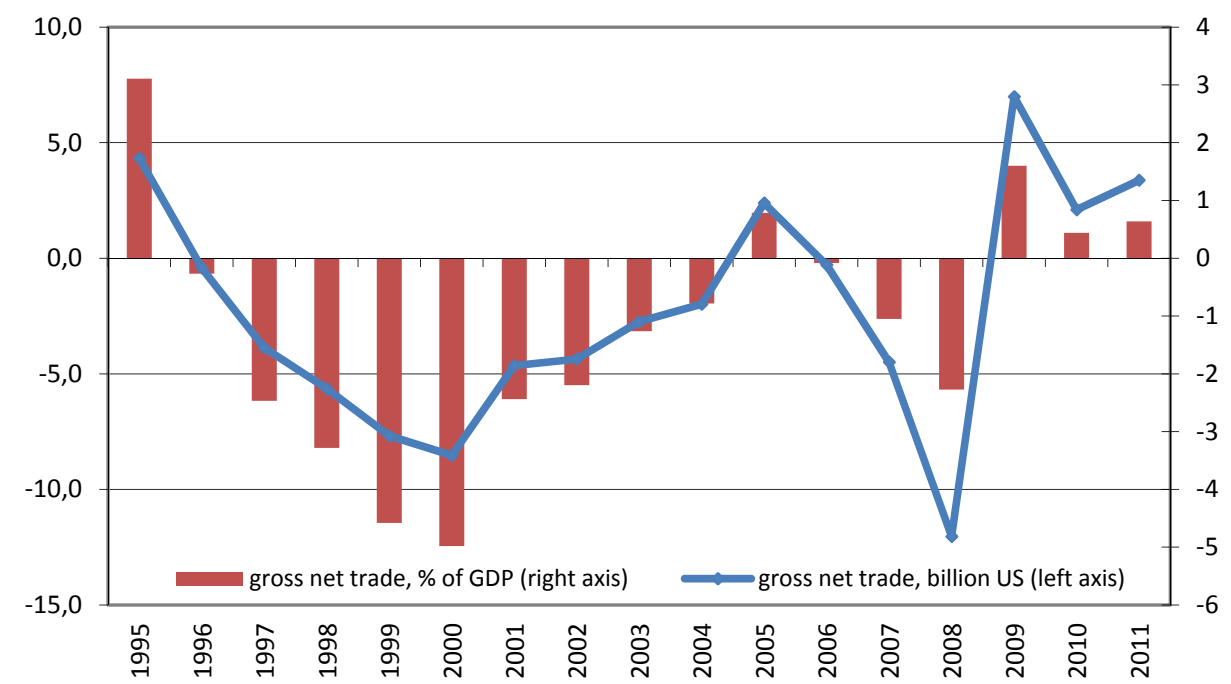

Figure 1. Net balance in Poland's trade in goods and services in 1995-2011 Source: own calculations based on WIOD.

Poland's bilateral trade balances in gross terms and in VA terms showed differences, quite significant at times (Table 1). In general, if Poland enjoyed trade surpluses with certain countries in gross terms, it also recorded surpluses in VA terms, but they were markedly lower. In the period under analysis it concerned trade with countries such as Germany, Denmark, Hungary, Lithuania, Latvia, Romania, and in the period of Poland's EU membership also with the United Kingdom, France, Sweden and Turkey. At times Poland recorded higher surpluses in VA terms than in gross terms in trade with Austria, Greece and Portugal. In some years the balance in gross terms was positive, whereas in VA terms negative in Poland's trade with Ireland, Germany, Canada and the Czech Republic.

With regard to the countries with which Poland had trade deficits in gross terms, deficits tended to be recorded also in VA terms, but they were lower. In the period covered it was true of trade with partners such as China, Russia, South Korea, Taiwan, Finland and Slovenia. At times deficit in VA terms was higher than in gross terms, e.g. in trade with Japan in the late 1990s. As regards trade with the United States, Turkey and Italy, some of the years witnessed Poland's trade surpluses in VA terms, whereas balances in gross terms were negative. 
Table 1. Bilateral trade balances in gross and value added terms in Poland, in $\%$ of GDP

\begin{tabular}{|c|c|c|c|c|c|c|c|c|c|c|c|c|c|c|c|}
\hline \multirow[t]{2}{*}{ Partner } & \multicolumn{5}{|c|}{ Gross trade } & \multicolumn{5}{|c|}{ Trade in value added } & \multicolumn{5}{|c|}{$\begin{array}{c}\text { Difference } \\
\text { (gross trade - trade in VA) }\end{array}$} \\
\hline & 1995 & 2000 & 2007 & 2009 & 2011 & 1995 & 2000 & 2007 & 2009 & 2011 & 1995 & 2000 & $|2007|$ & 2009 & 2011 \\
\hline AUS & 0.00 & \begin{tabular}{|l|}
-0.01 \\
\end{tabular} & -0.04 & 0.04 & 0.05 & 0.01 & \begin{tabular}{|l|}
-0.02 \\
\end{tabular} & \begin{tabular}{|l|}
-0.02 \\
\end{tabular} & 0.03 & 0.03 & -0.01 & 0.01 & -0.02 & 0.01 & 0.02 \\
\hline AUT & 0.06 & $\mid-0.31$ & 0.06 & 0.02 & 0.01 & 0.09 & -0.21 & 0.01 & 0.04 & 0.06 & -0.03 & -0.10 & 0.05 & $\mid-0.02$ & -0.05 \\
\hline BEL & \begin{tabular}{|l|}
-0.07 \\
\end{tabular} & \begin{tabular}{|l|}
-0.29 \\
\end{tabular} & -0.07 & 0.11 & -0.13 & -0.10 & -0.22 & -0.05 & 0.04 & -0.05 & 0.03 & -0.07 & \begin{tabular}{|l|}
-0.02 \\
\end{tabular} & 0.07 & -0.08 \\
\hline BGR & 0.01 & 0.04 & 0.16 & 0.12 & 0.05 & 0.00 & 0.02 & 0.11 & 0.09 & 0.05 & 0.01 & 0.02 & 0.05 & 0.03 & 0.00 \\
\hline BRA & 0.08 & \begin{tabular}{|l|}
-0.15 \\
\end{tabular} & -0.10 & -0.10 & -0.11 & 0.04 & -0.13 & -0.10 & -0.08 & -0.10 & 0.04 & -0.02 & 0.00 & \begin{tabular}{|l|}
-0.02 \\
\end{tabular} & -0.01 \\
\hline CAN & \begin{tabular}{|l|}
-0.02 \\
\end{tabular} & 0.08 & -0.04 & 0.16 & 0.20 & -0.01 & 0.00 & -0.05 & 0.09 & 0.06 & -0.01 & 0.08 & 0.01 & 0.07 & 0.14 \\
\hline $\mathrm{CHN}$ & \begin{tabular}{|l|}
-0.13 \\
\end{tabular} & \begin{tabular}{|l|}
-0.40 \\
\end{tabular} & -1.99 & -2.02 & -2.55 & -0.08 & \begin{tabular}{|l|}
-0.32 \\
\end{tabular} & -1.18 & -1.22 & -1.40 & -0.05 & -0.08 & -0.81 & \begin{tabular}{|l|}
-0.80 \\
\end{tabular} & -1.15 \\
\hline CYP & 0.01 & 0.01 & 0.01 & 0.01 & 0.00 & 0.01 & 0.01 & 0.01 & 0.01 & 0.01 & 0.00 & 0.00 & 0.00 & 0.00 & -0.01 \\
\hline CZE & 0.12 & \begin{tabular}{|l|}
-0.19 \\
\end{tabular} & 0.13 & 0.50 & 0.65 & 0.10 & -0.08 & -0.06 & 0.15 & 0.14 & 0.02 & -0.11 & .19 & 0.35 & 0.51 \\
\hline DEU & 3.44 & 3.09 & -0.56 & 0.76 & 0.93 & 2.30 & 1.01 & -1.09 & 0.09 & \begin{tabular}{|l|}
-0.04 \\
\end{tabular} & 1.14 & 2.08 & 0.53 & 0.67 & 0.97 \\
\hline DNK & 0.22 & 0.20 & 0.21 & 0.06 & 0.11 & 0.12 & \begin{tabular}{|l|}
-0.02 \\
\end{tabular} & 0.07 & 0.01 & 0.02 & 0.10 & 0.22 & 0.14 & 0.05 & 0.09 \\
\hline \begin{tabular}{|l|} 
ESP \\
\end{tabular} & \begin{tabular}{|l|}
-0.04 \\
\end{tabular} & \begin{tabular}{|l|}
-0.38 \\
\end{tabular} & 0.16 & 0.11 & 0.00 & 0.01 & -0.20 & $\begin{array}{ll}0.18 \\
\end{array}$ & 0.10 & \begin{tabular}{|l|}
-0.03 \\
\end{tabular} & -0.05 & \begin{tabular}{|l|}
-0.18 \\
\end{tabular} & \begin{tabular}{|l|}
-0.02 \\
\end{tabular} & 0.01 & 0.03 \\
\hline EST & \begin{tabular}{|l|}
-0.01 \\
\end{tabular} & 0.01 & 0.09 & 0.06 & 0.07 & 0.00 & 0.01 & 0.05 & 0.04 & 0.03 & -0.01 & 0.00 & 0.04 & 0.02 & 0.04 \\
\hline FIN & \begin{tabular}{|l|}
-0.04 \\
\end{tabular} & \begin{tabular}{|l|}
-0.31 \\
\end{tabular} & -0.21 & -0.13 & \begin{tabular}{|l|}
-0.06 \\
\end{tabular} & -0.04 & \begin{tabular}{|l|}
-0.24 \\
\end{tabular} & \begin{tabular}{|l|}
-0.10 \\
\end{tabular} & -0.03 & 0.01 & 0.00 & \begin{tabular}{|c|}
-0.07 \\
\end{tabular} & -0.11 & \begin{tabular}{|l|l|}
-0.10 \\
\end{tabular} & -0.07 \\
\hline \begin{tabular}{|l|} 
FRA \\
\end{tabular} & \begin{tabular}{|l|}
-0.12 \\
\end{tabular} & \begin{tabular}{|l|}
-0.88 \\
\end{tabular} & 0.06 & 0.52 & 0.58 & -0.09 & \begin{tabular}{|l|}
-0.67 \\
\end{tabular} & 0.05 & 0.43 & 0.44 & \begin{tabular}{|c|c|}
-0.03 \\
\end{tabular} & \begin{tabular}{|c|}
-0.21 \\
\end{tabular} & 0.01 & 0.09 & 0.14 \\
\hline GBR & \begin{tabular}{|l|}
-0.14 \\
\end{tabular} & \begin{tabular}{|l|}
-0.73 \\
\end{tabular} & 0.73 & 0.49 & 1.22 & -0.13 & \begin{tabular}{|l|}
-0.59 \\
\end{tabular} & 0.39 & 0.27 & 0.66 & \begin{tabular}{|c|} 
\\
\end{tabular} & \begin{tabular}{|l|}
-0.14 \\
\end{tabular} & 0.34 & 0.22 & 0.56 \\
\hline GRC & 0.02 & 0.09 & 0.15 & $\begin{array}{l}0.14 \\
\end{array}$ & 0.06 & 0.04 & 0.08 & 0.16 & 0.14 & 0.08 & \begin{tabular}{|c|c|} 
\\
\end{tabular} & 0.01 & -0.01 & 0.00 & -0.02 \\
\hline HUN & 0.15 & 0.07 & 0.18 & 0.11 & 0.22 & 0.11 & 0.06 & 0.11 & 0.09 & 0.08 & 0.04 & 0.01 & 0.07 & 0.02 & 0.14 \\
\hline IDN & 0.00 & \begin{tabular}{|l|}
-0.06 \\
\end{tabular} & 0.10 & -0.07 & -0.11 & 0.01 & -0.06 & 0.06 & -0.06 & -0.08 & -0.01 & 0.00 & 0.04 & \begin{tabular}{|c|}
-0.01 \\
\end{tabular} & -0.03 \\
\hline IND & \begin{tabular}{|l|}
-0.01 \\
\end{tabular} & \begin{tabular}{|l|}
-0.06 \\
\end{tabular} & -0.12 & -0.17 & -0.32 & 0.00 & -0.06 & -0.06 & -0.09 & -0.18 & -0.01 & 0.00 & \begin{tabular}{|l|}
-0.06 \\
\end{tabular} & \begin{tabular}{|l|}
-0.08 \\
\end{tabular} & -0.14 \\
\hline IRL & 0.03 & \begin{tabular}{|l|} 
\\
\end{tabular} & 0.21 & 0.09 & 0.02 & 0.01 & \begin{tabular}{|l|}
-0.09 \\
\end{tabular} & 0.03 & -0.05 & \begin{tabular}{|l|}
-0.03 \\
\end{tabular} & 0.02 & 0.02 & 0.18 & 0.14 & 0.05 \\
\hline ITA & \begin{tabular}{|l|}
-0.70 \\
\end{tabular} & \begin{tabular}{|l|}
-1.11 \\
\end{tabular} & -0.20 & 0.04 & \begin{tabular}{|l|}
-0.04 \\
\end{tabular} & -0.41 & \begin{tabular}{|l|}
-0.72 \\
\end{tabular} & -0.04 & 0.19 & 0.10 & \begin{tabular}{|c|c|} 
\\
\end{tabular} & \begin{tabular}{|l|} 
\\
\end{tabular} & \begin{tabular}{|l|}
-0.16 \\
\end{tabular} & -0.15 & -0.14 \\
\hline JPN & \begin{tabular}{|l|}
-0.19 \\
\end{tabular} & \begin{tabular}{|l|}
-0.43 \\
\end{tabular} & -0.46 & -0.41 & -0.44 & -0.16 & \begin{tabular}{|l|}
-0.48 \\
\end{tabular} & -0.46 & -0.37 & \begin{tabular}{|l|}
-0.36 \\
\end{tabular} & -0.03 & 0.05 & 0.00 & \begin{tabular}{|l|}
-0.04 \\
\end{tabular} & -0.08 \\
\hline KOR & \begin{tabular}{|l|}
-0.03 \\
\end{tabular} & \begin{tabular}{|l|}
-0.34 \\
\end{tabular} & -0.62 & \begin{tabular}{|l|}
-0.69 \\
\end{tabular} & \begin{tabular}{|l|}
-0.78 \\
\end{tabular} & -0.03 & \begin{tabular}{|l|}
-0.22 \\
\end{tabular} & -0.36 & -0.35 & \begin{tabular}{|l|}
-0.38 \\
\end{tabular} & 0.00 & -0.12 & \begin{tabular}{|c|}
-0.26 \\
\end{tabular} & \begin{tabular}{|l|}
-0.34 \\
\end{tabular} & -0.40 \\
\hline LTU & 0.08 & 0.04 & 0.39 & 0.29 & 0.33 & 0.06 & 0.05 & 0.22 & 0.20 & 0.19 & 0.02 & \begin{tabular}{|c|} 
\\
\end{tabular} & .17 & 0.09 & 0.14 \\
\hline LUX & \begin{tabular}{|l|}
-0.09 \\
\end{tabular} & \begin{tabular}{|l|}
-0.24 \\
\end{tabular} & -0.02 & $\begin{array}{ll}0.02 \\
\end{array}$ & -0.06 & -0.04 & -0.08 & \begin{tabular}{|l|}
-0.02 \\
\end{tabular} & -0.01 & \begin{tabular}{|l|}
-0.03 \\
\end{tabular} & -0.05 & \begin{tabular}{|c|}
-0.16 \\
\end{tabular} & 0.00 & 0.03 & -0.03 \\
\hline LVA & 0.03 & 0.08 & 0.21 & 0.16 & 0.15 & 0.02 & 0.05 & 0.15 & 0.10 & 0.09 & 0.01 & 0.03 & 0.06 & 0.06 & 0.06 \\
\hline MEX & 0.06 & 0.02 & -0.04 & 0.01 & 0.00 & 0.04 & 0.01 & -0.03 & 0.02 & 0.00 & 0.02 & 0.01 & \begin{tabular}{|l|}
-0.01 \\
\end{tabular} & $\mid-0.01$ & 0.00 \\
\hline MLT & \begin{tabular}{|l|}
-0.01 \\
\end{tabular} & 0.00 & -0.01 & -0.01 & \begin{tabular}{|l|} 
\\
\end{tabular} & 0.00 & 0.00 & 0.00 & -0.01 & 0.00 & -0.01 & 0.00 & \begin{tabular}{|l|}
-0.01 \\
\end{tabular} & 0.00 & -0.01 \\
\hline NLD & \begin{tabular}{|l|} 
\\
\end{tabular} & \begin{tabular}{|l|}
-0.40 \\
\end{tabular} & -0.49 & -0.29 & -0.35 & -0.14 & -0.31 & -0.34 & -0.16 & \begin{tabular}{|l|}
-0.23 \\
\end{tabular} & -0.07 & \begin{tabular}{|l|}
-0.09 \\
\end{tabular} & \begin{tabular}{|l|} 
\\
\end{tabular} & \begin{tabular}{|l|}
-0.13 \\
\end{tabular} & -0.12 \\
\hline $\mathrm{POL}$ & 0.00 & 0.00 & 0.00 & 0.00 & 0.00 & 0.00 & 0.00 & 0.00 & 0.00 & 0.00 & 0.00 & 0.00 & 0.00 & 0.00 & 0.00 \\
\hline \begin{tabular}{|l|} 
PRT \\
\end{tabular} & 0.01 & 0.04 & 0.00 & 0.01 & 0.01 & 0.02 & 0.04 & 0.03 & 0.04 & 0.04 & \begin{tabular}{|c|}
-0.01 \\
\end{tabular} & 0.00 & \begin{tabular}{|l|}
-0.03 \\
\end{tabular} & \begin{tabular}{|l|}
-0.03 \\
\end{tabular} & -0.03 \\
\hline ROM & 0.05 & 0.08 & 0.39 & 0.29 & 0.34 & 0.04 & 0.06 & 0.28 & 0.21 & 0.22 & 0.01 & 0.02 & 0.11 & 0.08 & 0.12 \\
\hline RUS & \begin{tabular}{|l|}
-0.33 \\
\end{tabular} & \begin{tabular}{|l|}
-1.21 \\
\end{tabular} & -1.21 & \begin{tabular}{|l|}
-0.03 \\
\end{tabular} & \begin{tabular}{|l|}
-0.82 \\
\end{tabular} & 0.08 & \begin{tabular}{|l|}
-0.97 \\
\end{tabular} & \begin{tabular}{|c|}
-0.82 \\
\end{tabular} & -0.04 & \begin{tabular}{|l|}
-0.30 \\
\end{tabular} & \begin{tabular}{|c|}
-0.41 \\
\end{tabular} & \begin{tabular}{|l|}
-0.24 \\
\end{tabular} & \begin{tabular}{|c|}
-0.39 \\
\end{tabular} & 0.01 & -0.52 \\
\hline SVK & \begin{tabular}{|l|}
-0.02 \\
\end{tabular} & \begin{tabular}{|l|}
-0.12 \\
\end{tabular} & -0.22 & -0.23 & -0.16 & -0.01 & \begin{tabular}{|l|}
-0.03 \\
\end{tabular} & -0.05 & -0.05 & \begin{tabular}{|l|}
-0.03 \\
\end{tabular} & \begin{tabular}{|c|} 
\\
\end{tabular} & \begin{tabular}{|c|}
-0.09 \\
\end{tabular} & \begin{tabular}{|l|}
-0.17 \\
\end{tabular} & \begin{tabular}{|l|}
-0.18 \\
\end{tabular} & -0.13 \\
\hline SVN & \begin{tabular}{|l|}
-0.03 \\
\end{tabular} & \begin{tabular}{|l|}
-0.07 \\
\end{tabular} & -0.07 & -0.03 & 0.00 & -0.01 & -0.04 & -0.03 & -0.02 & 0.00 & -0.02 & -0.03 & -0.04 & \begin{tabular}{|l|}
-0.01 \\
\end{tabular} & 0.00 \\
\hline SWE & \begin{tabular}{|l|}
-0.06 \\
\end{tabular} & 0.00 & 0.56 & 0.57 & 0.29 & -0.06 & \begin{tabular}{|l|}
-0.05 \\
\end{tabular} & 0.20 & 0.27 & 0.15 & 0.00 & 0.05 & 0.36 & 0.30 & 0.14 \\
\hline TUR & 0.01 & -0.03 & -0.09 & 0.13 & 0.21 & 0.03 & 0.00 & 0.01 & 0.11 & 0.18 & \begin{tabular}{|l}
-0.02 \\
\end{tabular} & -0.03 & \begin{tabular}{|c|}
-0.10 \\
\end{tabular} & 0.02 & 0.03 \\
\hline TWN & 0.00 & \begin{tabular}{|l|}
-0.15 \\
\end{tabular} & -0.23 & -0.11 & \begin{tabular}{|l|}
-0.08 \\
\end{tabular} & -0.01 & \begin{tabular}{|l|}
-0.11 \\
\end{tabular} & -0.16 & -0.10 & \begin{tabular}{|l|}
-0.06 \\
\end{tabular} & 0.01 & -0.04 & \begin{tabular}{|l|}
-0.07 \\
\end{tabular} & \begin{tabular}{|l|}
-0.01 \\
\end{tabular} & -0.02 \\
\hline USA & 0.19 & \begin{tabular}{|l|}
-0.17 \\
\end{tabular} & -0.16 & -0.53 & -0.70 & 0.23 & \begin{tabular}{|l|} 
\\
\end{tabular} & 0.12 & -0.24 & \begin{tabular}{|l|}
-0.33 \\
\end{tabular} & -0.04 & -0.05 & \begin{tabular}{|l|}
-0.28 \\
\end{tabular} & \begin{tabular}{|l|}
-0.29 \\
\end{tabular} & -0.37 \\
\hline RoW & 0.81 & \begin{tabular}{|l|}
-0.71 \\
\end{tabular} & 2.07 & 1.61 & 1.83 & 1.05 & \begin{tabular}{|l|}
-0.35 \\
\end{tabular} & 1.72 & 1.74 & 1.63 & \begin{tabular}{|c|}
-0.24 \\
\end{tabular} & -0.36 & 0.35 & \begin{tabular}{|l|}
-0.13 \\
\end{tabular} & 0.20 \\
\hline Total & 3.11 & \begin{tabular}{|l|}
-4.98 \\
\end{tabular} & -1.05 & 1.60 & 0.64 & 3.11 & -4.98 & \begin{tabular}{|c|}
-1.05 \\
\end{tabular} & 1.60 & 0.64 & 0.00 & 0.00 & 0.00 & 0.00 & 0.00 \\
\hline
\end{tabular}

Source: own elaboration based on WIOD database. 
In the years 1995-2011, Poland's trade with the majority of the countries (with the exception of Germany and Italy, among others) was characterised by widening gaps between balances in gross terms and those in VA terms, as measured by the ratio of those balances to Poland's gross domestic product (Figure 2). It stemmed from Poland's participation in the processes of production fragmentation, which resulted in the increased importance of intermediate goods in the Polish trade. Such goods were excluded from VA statistics.

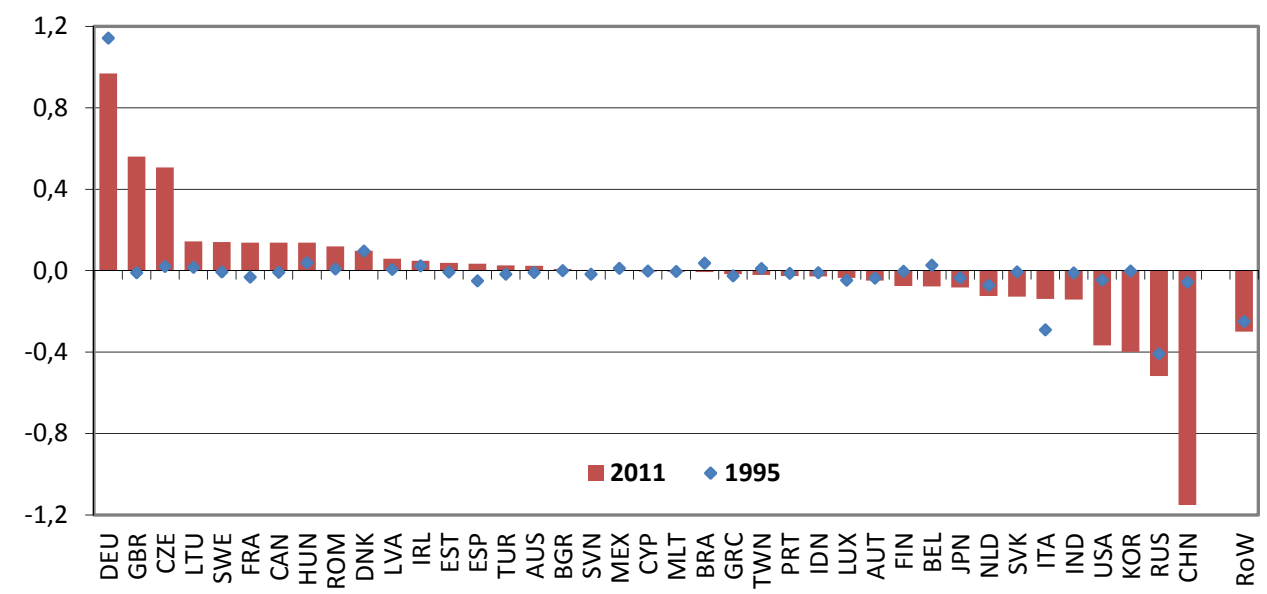

Figure 2. Differences between gross and value added trade in Poland's bilateral trade in 1995 and 2011, in \% of GDP

Source: own calculations based on WIOD.

In 2011, in gross terms, Poland enjoyed the highest surpluses in trade with the United Kingdom (USD 6.4 billion), Germany (USD 4.9 billion), the Czech Republic (USD 3.4 billion), France (USD 3.0 billion) and Romania (USD 1.8 billion). In VA terms, surpluses were only noted with four of the above-mentioned countries (Figure 3). Furthermore, those were markedly lower than the figures computed on the basis of traditional statistics - nearly by half in trade with the United Kingdom and almost 80\%, 24\% and 35\% lower in trade with the Czech Republic, France and Romania, respectively. At the same time, the balance of Poland's trade with Germany in VA terms was negative (USD - 0.2 billion).

In 2011 the greatest deficits in gross terms were noted in Poland's trade with China (USD 13.5 billion), Russia (USD 4.3 billion), South Korea (USD 4.1 billion), the United States (USD 3.7 billion) and Japan (USD 2.3 billion). In VA terms deficits in trade with the aforementioned countries were markedly lower. The highest deficit in VA terms still characterised Poland's trade with China, although it was nearly by $50 \%$ lower than in gross terms. Negative balances in VA terms were less than half of those in gross terms in the Polish trade with South Korea and the United States, and nearly 65\% lower in trade with Russia. Poland's trade deficit with Japan in VA statistics was only $18 \%$ lower than the figure calculated using traditional statistics. 


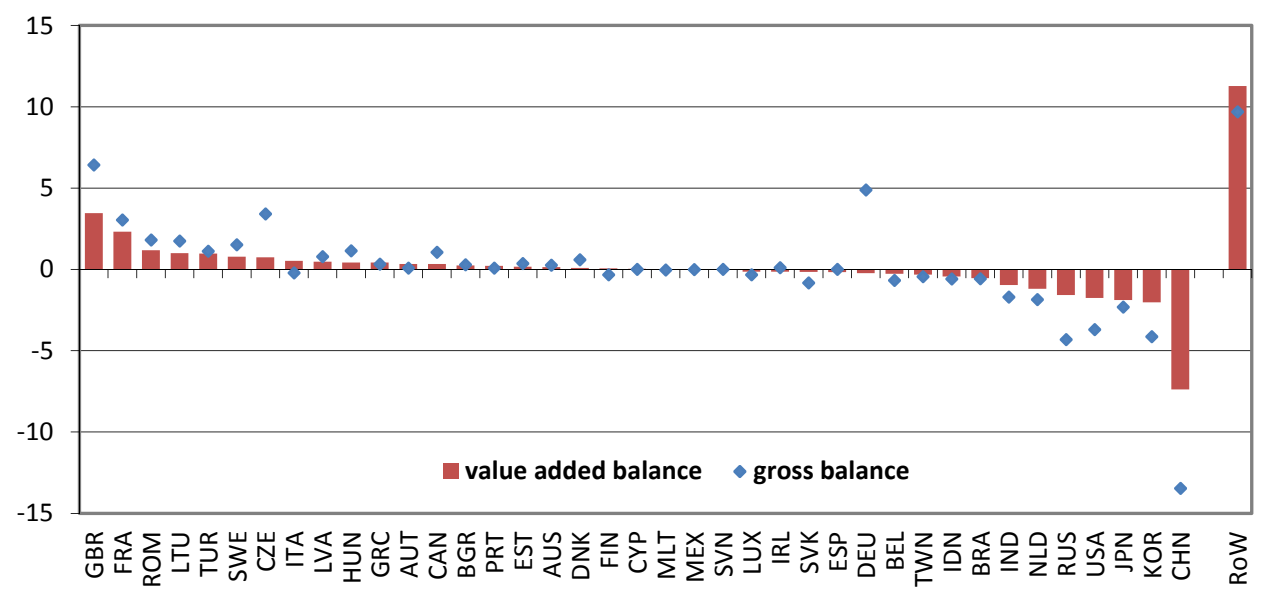

Figure 3. Poland's bilateral net trade in gross and value added terms in 2011, in US billion Source: own calculations based on WIOD.

\section{Decomposition of Poland's Bilateral Imbalances by Value Added Content}

The decomposition of Poland's bilateral trade, i.e. exports and imports, by VA content made it possible to decompose bilateral trade balances. It allowed to explain differences between balances in gross terms and those in VA terms in Poland's bilateral trade. The analysis covered all the trading partners of Poland, but this paper only discusses the group of countries in trade with which gaps between the values of balances computed with the use of the two methods were the widest.

The decomposition of trade balances by VA content demonstrated that the differences in the value of trade balances in gross terms and in VA terms had been mostly determined by two components: (1) 'multilateral VA net exports to third countries via partner' and (2) 'foreign VA in exports from other countries than partner' (Table 2).

Among the countries with which Poland enjoyed surpluses in gross terms, in 2011 the highest differences in trade balances in gross terms and in VA terms characterised the Polish trade with Germany (balance in gross terms higher than that in VA terms by $0.97 \%$ of GDP), the United Kingdom (by $0.56 \%$ of GDP) and the Czech Republic (by $0.51 \%$ of GDP) and, to a lesser extent, also with Lithuania, Sweden, France, Canada, Hungary and Romania (by approximately $0.15 \%$ of GDP).

In trade with Germany, the Czech Republic and Hungary differences in the values of balances in gross terms and VA terms were mainly attributable to a positive component 'multilateral value added (MVA) net exports to third countries via partner'. It means that Poland exported more of its value added to the third countries via the three abovementioned countries than these countries exported their VA via Poland to third countries. A major share of Polish exports to Germany, the Czech Republic and Hungary were parts and components absorbed by those countries in export-oriented production. Thus, the most important factor explaining differences in Poland's trade with the three abovementioned trade partners was demand in countries other than these trade partners. An 
example of this phenomenon is the export of Polish engines from the Volkswagen plant near Poznań to German factories manufacturing cars exported to China.

Table 2. Decomposition of Poland's bilateral gross trade balance by VA content in 2011, in US million

\begin{tabular}{|c|c|c|c|c|c|c|c|c|c|c|c|}
\hline \multirow[b]{2}{*}{ Country } & \multirow[b]{2}{*}{$\begin{array}{c}\text { Net gross } \\
\text { exports }\end{array}$} & \multicolumn{4}{|c|}{ Net value added exports } & \multirow{2}{*}{$\begin{array}{c}\text { Re- } \\
\text { turned } \\
\text { domes- } \\
\text { tic VA }\end{array}$} & \multicolumn{3}{|c|}{ Foreign VA in net exports } & \multicolumn{2}{|c|}{$\begin{array}{c}\text { Multilateral VA } \\
\text { net exports }\end{array}$} \\
\hline & & Total & $\begin{array}{l}\text { Final } \\
\text { goods }\end{array}$ & $\begin{array}{c}\text { In- } \\
\text { terme- } \\
\text { diates }\end{array}$ & Indirect & & Total & $\begin{array}{l}\text { from } \\
\text { part- } \\
\text { ner }\end{array}$ & $\begin{array}{l}\text { from } \\
\text { others }\end{array}$ & $\begin{array}{c}\text { to } 3 r d \\
\text { coun- } \\
\text { tries via } \\
\text { partner }\end{array}$ & $\begin{array}{l}\text { via } 3 r d \\
\text { coun- } \\
\text { tries to } \\
\text { partner }\end{array}$ \\
\hline AUS & 269.0 & 144.0 & 187.1 & -46.6 & 3.5 & -1.4 & 158.1 & 1.4 & 156.7 & -410.2 & 378.5 \\
\hline AUT & 76.9 & 336.6 & 262.1 & -109.8 & 184.2 & 11.0 & -145.7 & -11.0 & -134.6 & 155.1 & -280.3 \\
\hline BEL & -670.3 & -263.3 & 150.3 & -440.3 & 26.6 & 1.1 & -929.3 & -1.1 & -928.1 & 442.9 & 78.2 \\
\hline BGR & 287.4 & 240.0 & 137.3 & 73.7 & 29.0 & 2.2 & 77.9 & -2.2 & 80.1 & 5.9 & -38.6 \\
\hline BRA & -569.1 & -533.0 & -292.3 & -86.4 & -154.3 & -1.2 & 47.3 & 1.2 & 46.1 & -642.2 & 560.0 \\
\hline CAN & $1,060.8$ & 332.0 & 110.9 & 136.7 & 84.4 & -6.8 & 589.6 & 6.8 & 582.8 & -138.4 & 284.5 \\
\hline $\mathrm{CHN}$ & $-13,458.3$ & $-7,375.3$ & $-5,205.3$ & $-1,598.5$ & -571.5 & -80.5 & $-2,692.3$ & 80.5 & $-2,772.7$ & $-4,209.1$ & 898.9 \\
\hline CYP & 9.8 & 35.3 & 6.2 & 15.5 & 13.6 & 0.4 & -1.9 & -0.4 & -1.5 & -4.2 & -19.8 \\
\hline CZE & $3,416.3$ & 738.1 & 572.1 & 203.1 & -37.2 & 109.2 & 522.3 & -109.2 & 631.5 & $2,055.3$ & -8.6 \\
\hline DEU & $4,893.8$ & -224.5 & $2,113.2$ & $-2,493.5$ & 155.8 & $-3,462.9$ & $5,313.6$ & $3,462.9$ & $1,850.7$ & $3,319.2$ & -51.6 \\
\hline DNK & 598.1 & 83.4 & -10.7 & 37.0 & 57.1 & 14.8 & 155.3 & -14.8 & 170.1 & 415.0 & -70.4 \\
\hline ESP & 11.0 & -168.8 & -357.0 & 44.6 & 143.5 & -35.1 & 808.0 & 35.1 & 773.0 & -403.8 & -189.3 \\
\hline EST & 370.9 & 166.2 & 115.1 & 46.0 & 5.1 & 2.8 & 131.7 & -2.8 & 134.5 & 71.5 & -1.3 \\
\hline FIN & 8.4 & 68.2 & 6.3 & -115.5 & & 4.6 & & -4.6 & -178.6 & -236.4 & 18.4 \\
\hline FRA & $3,047.2$ & $2,318.1$ & 1,006.1 & 688.1 & 623.9 & -150.0 & $1,731.7$ & 150.0 & $1,581.7$ & -0.6 & -852.0 \\
\hline GBR & $6,426.5$ & $3,464.0$ & $2,495.4$ & 455.3 & 513.3 & -147.3 & $3,370.9$ & 147.3 & $3,223.5$ & -221.4 & -39.7 \\
\hline GRC & 331.3 & 420.7 & 129.9 & 169.4 & 121.4 & 0.3 & 145.6 & -0.3 & 145.9 & -51.3 & -184.0 \\
\hline HUN & $1,150.0$ & 424.8 & 498.7 & -120.1 & 46.3 & 40.6 & -38.8 & -40.6 & 1.8 & 913.3 & -190.0 \\
\hline IDN & -585.2 & 5.0 & 5.1 & -1 & & 0.1 & & -0.1 & -110.2 & -352.7 & 312.7 \\
\hline IND & $-1,704.3$ & -955.5 & -692.3 & -208.3 & -54.9 & -0.1 & -251.2 & 0.1 & -251.3 & -563.5 & 66.1 \\
\hline IRL & 109.6 & -146.9 & -107.8 & -11.4 & -27.7 & 2.9 & -280.9 & -2.9 & -278.1 & 441.6 & 92.9 \\
\hline ITA & -205.9 & 526.7 & 467.4 & -214.5 & 273.8 & -223.4 & $1,326.9$ & 223.4 & $1,103.5$ & $-1,600.2$ & -235.9 \\
\hline JPN & $-2,317.1$ & $-1,881.7$ & -839.4 & -644.9 & -397.4 & -4.4 & -259.9 & 4.4 & -264.3 & $-1,281.0$ & $1,109.8$ \\
\hline KOR & $-4,131.6$ & $-2,024.0$ & -761.8 & $-1,043.2$ & -219.0 & -0.6 & $-1,512.8$ & 0.6 & $-1,513.5$ & $-1,068.6$ & 474.5 \\
\hline LTU & $1,754.8$ & 994.4 & 743.5 & 229.3 & 21.6 & 18.4 & 594.8 & 18.4 & 613.2 & 171.4 & -24.3 \\
\hline LUX & -327.5 & -143.0 & -0.3 & -140.9 & -1.7 & 4.0 & -287.7 & -4.0 & -283.6 & 81.5 & 17.6 \\
\hline LVA & 784.8 & 472.2 & 281.3 & 165.5 & 25.3 & 3.2 & 261.2 & -3.2 & 264.4 & 83.3 & -35.0 \\
\hline MEX & -5.2 & -9.3 & -36.2 & -25.9 & 52.7 & -0.6 & 106.7 & 0.6 & 106.1 & -37.1 & -64.8 \\
\hline MLT & -30.4 & -2.0 & -1.0 & -6.2 & 5.2 & 0.3 & -20.8 & -0.3 & -20.5 & 0.5 & -8.5 \\
\hline NLD & $-1,849.6$ & $-1,189.8$ & -132.4 & -946.5 & -110.8 & -15.3 & $-1,171.1$ & 15.3 & $-1,186.4$ & -121.1 & 647.6 \\
\hline PRT & 78.8 & 218.5 & 115.3 & -4.9 & 108.0 & 0.6 & 53.9 & -0.6 & 54.5 & -83.1 & -111.0 \\
\hline ROM & 809.8 & $1,180.3$ & 566.4 & 547.1 & 66.7 & 4.8 & 721.3 & -4.8 & 726.1 & 16.2 & -112.7 \\
\hline RUS & $-4,313.6$ & $-1,580.2$ & $4,182.8$ & $-5,679.6$ & -83.4 & -353.1 & $3,010.3$ & 353.1 & $2,657.2$ & $-7,469.2$ & $2,078.6$ \\
\hline SVK & -829.1 & -156.0 & 240.3 & -401.9 & 5.7 & 37.3 & -515.7 & -37.3 & -478.4 & -146.4 & -48.4 \\
\hline SVN & 7.5 & -10.7 & 6.1 & -30.4 & 13.7 & 4.7 & -12.0 & -4.7 & -7.3 & 37.5 & -12.0 \\
\hline SWE & 524.7 & 780.9 & 627.1 & 62.8 & 90.9 & -8.1 & 615.2 & 8.1 & 607.2 & 110.7 & 25.9 \\
\hline TUR & $1,117.0$ & 871.0 & 807.8 & -152.4 & 215.6 & -14.3 & 964.2 & 14.3 & 950.0 & -507.9 & -196.0 \\
\hline TWN & -436.4 & -324.4 & -66.9 & -113.9 & -143.7 & 0.5 & -348.8 & -0.5 & -348.3 & -55.2 & 291.5 \\
\hline USA & $-3,694.2$ & $-1,756.2$ & $-1,344.0$ & -832.8 & 420.6 & -134.3 & 918.8 & 134.3 & 784.5 & $-3,252.9$ & 530.4 \\
\hline RoW & $9,693.6$ & $8,737.8$ & $4,396.9$ & $4,067.9$ & 272.9 & $-1,550.0$ & $5,678.4$ & $1,550.0$ & $4,128.4$ & $-3,343.1$ & 170.5 \\
\hline
\end{tabular}

Source: own elaboration based on WIOD database. 
A further breakdown of 'MVA net exports to third countries via partner' showed which countries mattered to the third-country demand effect in the gross balances in Poland's trade with Germany, the Czech Republic and Hungary (Table 3). In 2011 demand from China, the United States, France and Austria explained over 53\% of the gross trade surplus between Poland and Germany. It means that Poland benefited from the trade cooperation with Germany which exports Polish value added to these four countries. In turn, demand from some countries, mainly from the Czech Republic, Russia, Italy and Turkey, led to a reduction in the Polish-German trade surplus. It means that Poland exported to those countries less value added via Germany than Germany exported to those countries its value added via Poland.

Table 3. Decomposition of 'multilateral VA net exports to 3rd countries via partner' (by demand country) in Poland's net trade with selected trade partners, in US million

\begin{tabular}{|c|c|c|c|c|c|c|c|c|}
\hline & \multicolumn{8}{|c|}{ Poland's trade partners } \\
\hline & 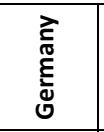 & 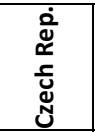 & 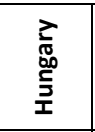 & 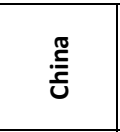 & $\frac{\pi}{\tilde{y}}$ & 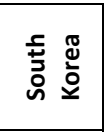 & 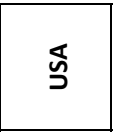 & $\stackrel{2}{ \pm}$ \\
\hline Gross net trade & 4893.8 & 3416.3 & 1150.0 & -13458.3 & -4313.6 & -4131.6 & -3694.2 & -205.9 \\
\hline $\begin{array}{l}\text { Multilateral VA net exports to } \\
\text { 3rd countries via partner }\end{array}$ & 3319.2 & 2055.3 & 892.3 & -4209.1 & -7469.2 & -1072.6 & -3252.9 & -1600.2 \\
\hline \multicolumn{9}{|l|}{ including: } \\
\hline Austria & 463.8 & 191.5 & 63.5 & -80.6 & -263.8 & -23.4 & -77.8 & -12.5 \\
\hline China & 971.5 & 36.2 & 50.7 & - & -27.4 & 91.7 & 47.0 & 38.2 \\
\hline Czech Rep. & -365.4 & - & 12.4 & -241.1 & -550.7 & -68.8 & -216.5 & -163.6 \\
\hline Germany & - & 795.0 & 294.4 & $-1,322.6$ & $-2,077.4$ & -358.5 & $-1,047.9$ & -719.5 \\
\hline France & 506.0 & 107.6 & 45.1 & -330.6 & -426.2 & -96.6 & -245.2 & -28.5 \\
\hline United Kingdom & -62.8 & 57.0 & 62.9 & -334.2 & -469.4 & -100.5 & -240.9 & -161.7 \\
\hline Hungary & -113.9 & 42.9 & - & -143.5 & -151.1 & -40.5 & -104.7 & -73.6 \\
\hline Italy & -128.6 & 45.5 & 27.9 & -327.9 & -237.8 & -95.6 & -252.0 & - \\
\hline Russia & -261.3 & 66.2 & 4.9 & -310.2 & - & -56.6 & -219.6 & -144.7 \\
\hline USA & 671.8 & 52.7 & 30.5 & 111.5 & -126.3 & -2.6 & - & 26.4 \\
\hline Others & $1,638.1$ & 660.7 & 300.1 & $-1,229.8$ & $-3,139.2$ & -321.1 & -895.4 & -360.6 \\
\hline
\end{tabular}

Source: own elaboration based on WIOD database.

At the same time, German demand accounted for ca. $1 / 4$ of gross surpluses in Poland's trade with the Czech Republic and Hungary. The other countries contributing to the surplus in the Polish-Czech trade included Austria (6\% of the gross surplus in Poland's trade with the Czech Republic), Slovakia (5\%), France (3\%), Russia (2\%) and the United Kingdom (2\%). The surplus in Poland's trade with Hungary was - in addition to Germany also generated by: Austria and the United Kingdom (6\% of the gross surplus in Poland's trade with Hungary each), Romania (5\%), as well as France and China (4\% each).

As regards other countries characterised by the greatest differences between surpluses in gross terms and in VA terms, the gaps were explained mainly by the component 'foreign VA in net exports from other countries than partner' (Table 4). In 2011 that component had the highest value in Poland's trade with the United Kingdom - USD 3.2 billion. It accounted for more than half of the gross surplus in trade between Poland and the United Kingdom. The high importance of that component resulted from the fact that Polish exports to the United King- 
dom of German, Chinese, Russian and US value added were higher than Polish imports from the United Kingdom of the value added created in those countries. The positive balance in trade in German value added between Poland and the United Kingdom accounted for $12 \%$ of the surplus in Polish-British trade and the positive balance in trade in Russian value added - for $7 \%$ of that surplus. The positive component 'FVA in net exports from other countries than partner' in Poland's trade with the above-mentioned countries depended on the demand of these trade partners for products brought from Poland and containing foreign value added.

At the same time, Poland imported from Canada more US value added than it exported US value added to Canada. In Poland's trade with Lithuania, Romania and Sweden the positive component 'FVA net trade' did not exceed $40 \%$ of the value of gross surplus.

Table 4. Decomposition of 'FVA in net exports' (by country of VA origin) in Poland's net trade with selected trade partners in 2011, in US million

\begin{tabular}{|c|c|c|c|c|c|c|c|c|c|c|c|}
\hline & 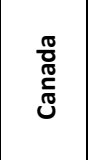 & : & 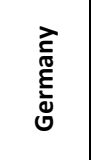 & ֻัّ & 弚 & $\frac{2}{ \pm}$ & 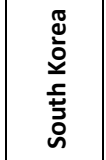 & 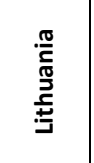 & $\begin{array}{l}\frac{n}{0} \\
\frac{1}{\pi} \\
\frac{\pi}{2} \\
\frac{ \pm}{2} \\
\frac{ \pm}{2}\end{array}$ & $\frac{\pi}{\sqrt[n]{n}}$ & 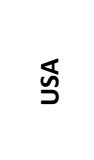 \\
\hline Gross net trade & 1060.8 & -13458.3 & 4893.8 & 3047.2 & 6426.5 & -205.9 & -4131.6 & 1754.8 & -1849.6 & -4313.6 & -3694.2 \\
\hline $\begin{array}{l}\text { Foreign VA in } \\
\text { exports from: }\end{array}$ & 582.8 & -2772.7 & 1850.7 & 1581.7 & 3223.5 & 1103.5 & -1513.5 & 613.2 & -1186.4 & 2657.2 & 784.5 \\
\hline China & 35.4 & - & 240.1 & 172.7 & 239.0 & 113.7 & -377.1 & 41.7 & -78.4 & 228.2 & 10.1 \\
\hline Czech Rep. & 19.0 & 23.3 & 143.9 & 88.3 & 107.5 & 81.7 & 1.8 & 16.4 & 20.6 & 78.7 & 47.7 \\
\hline Germany & 157.9 & 35.8 & - & 436.7 & 797.6 & 542.4 & -28.4 & 111.5 & -84.0 & 653.8 & 366.3 \\
\hline France & 28.4 & -15.9 & -137.1 & - & 106.4 & -23.1 & -18.2 & 23.9 & -63.7 & 123.4 & 60.3 \\
\hline UK & 19.2 & -12.9 & -124.5 & -0.8 & - & 37.7 & -14.9 & 26.9 & -199.5 & 110.8 & 32.5 \\
\hline Italy & 42.5 & -1.3 & 209.1 & 57.5 & 194.5 & - & -5.5 & 25.0 & 16.3 & 172.0 & 92.9 \\
\hline Japan & 11.1 & -378.7 & -1.7 & 34.3 & 61.2 & 52.7 & -183.0 & 10.6 & -46.8 & 14.7 & -16.6 \\
\hline South Korea & 12.9 & -240.0 & 153.5 & 58.2 & 83.1 & 36.9 & - & 10.8 & -2.4 & 15.4 & 20.7 \\
\hline Netherlands & 18.2 & -7.1 & -278.0 & 8.9 & 51.4 & 8.8 & -4.3 & 16.8 & - & 88.4 & 40.8 \\
\hline Russia & 62.1 & -23.6 & 1542.0 & 318.4 & 436.3 & 90.6 & -29.4 & 33.8 & 132.6 & - & 142.4 \\
\hline USA & -33.5 & -364.5 & 66.3 & 30.7 & 68.7 & 77.2 & -180.5 & 42.6 & -211.5 & 177.7 & - \\
\hline Others & 209.6 & -1787.8 & 37.1 & 376.8 & 1077.7 & 84.8 & -673.9 & 253.3 & -669.6 & 994.1 & -12.7 \\
\hline
\end{tabular}

Source: own elaboration based on WIOD database.

Another, equally numerous group of Poland's trading partners were countries with which Poland had trade deficits both in gross terms and in VA terms, with the value of that deficit being higher in gross terms. The greatest differences characterised deficits in both approaches in Poland's trade with China (the difference represented $1.15 \%$ of Poland's GDP), Russia ( $0.52 \%$ of GDP), South Korea ( $0.40 \%$ of GDP), the United States $(0.37 \%$ of GDP), as well as with Indonesia, Italy, Slovakia, the Netherlands and Japan (below $0.15 \%$ of GDP).

Lower balances in gross terms than in VA terms in Poland's trade with the aforementioned countries mostly stemmed from the negative value of the component 'MVA net exports to third countries via partner'. It means that Poland's trading partners exported more to third countries via Poland than Poland exported to third countries via its trading partners. In the Polish trade with China the component 'MVA net exports to third countries via partner' accounted for over $31 \%$ of the deficit between the partners. 
The greatest contribution was that of German demand for Chinese value added. It represented nearly $10 \%$ of the Polish-Chinese trade deficit in gross terms. An important role was also played by demand from Russia, France, the United Kingdom and Italy which explained another $10 \%$ of the gross deficit between Poland and China. Poland imported from China parts and components for the production of radio and television equipment and household appliances to be exported to the European Union.

In Poland's trade with Russia the negative value of the component 'MVA net exports to third countries via partner' was USD minus 7.5 billion, higher than the deficit in gross terms (other components had a positive effect on the deficit). It was mostly contributed to by Germany's demand for Russian value added contained in products originating from Poland. The demand explained nearly half of the deficit in the Polish trade with Russia.

The component 'MVA net exports to third countries via partner' was also important to the generation of gross deficit in Poland's trade with the USA. The value of that component represented $88 \%$ of the gross deficit between the two countries. First and foremost, Poland exported to Germany via the United States markedly less Polish value added than the US exported US value added to Germany via Poland. The negative value of the component 'MVA net exports to third countries via partner' also resulted from demand for US value added contained in Polish exports to Italy, France, the Czech Republic and Russia. At the same time, demand from Canada and Mexico had a downward effect on the gross balance in Poland's trade with the United States. It means that Poland exported to Mexico and Canada via the US more Polish value added than the US exported to the two countries US value added via Poland.

As regards Poland's trade with South Korea, the component 'MVA net exports' played a lesser role in generating gross deficit between the countries in question. The value of that component represented $26 \%$ of the gross deficit between the two countries. The negative value of the component was mostly caused by demand from Germany, Italy, the United Kingdom and France for Korean value added contained in Polish exports.

In Poland's trade with China, the Netherlands and South Korea some of the differences in gross balances and balances in VA terms were attributable to the negative component 'FVA in net exports'. At the same time, in trade with Russia, Italy, the United States the component concerned was positive. The negative value of the component in the Polish trade with China means that Poland's imports from China contained more foreign VA than Poland's exports to China. As regards foreign VA in imports from China, it was mostly value added created in other South Asian countries (in Japan, South Korea, Taiwan), as well as in the United States and Australia. Similar countries contributed the most to foreign VA content of Polish imports from South Korea. The negative component 'FVA in net exports' in the Polish trade with the Netherlands primarily resulted from the fact that Poland's imports from the Netherlands contained relatively much British, Belgian and US value added.

The positive value of the component in Poland's trade with Russia and Italy indicates that Poland exported more foreign VA to the countries concerned than it imported from them. Poland exported to Russia products containing value added created mostly in Germany, China and Italy, whereas to Italy - products containing value added originating in Germany, China, the United States and Russia.

Thus, the study confirmed that Poland traded with its trading partners not only directly but also more and more often indirectly via other trading partners. The indirect trade was 
especially important in Poland's trade with the USA, China, Germany, Italy, Japan, the Czech Republic and Russia. To access benefits derived by Poland from the international trade it is recommended to use trade statistics in value added terms. Only these statistics allow to determine how much of the value added created in a country is not only directly but also indirectly embodied in the final consumption of another country. No physical shipment of good between two countries may mean that trade in value added occurs.

\section{CONCLUSIONS}

According to the study carried out, if Poland enjoyed trade surpluses with certain countries in gross terms, it also recorded surpluses in VA terms, but they were markedly lower. In the period under analysis it concerned trade with countries such as Germany, Denmark, Hungary, Lithuania, Latvia, Romania, and in the period of Poland's EU membership also with the United Kingdom, France, Sweden and Turkey. With regard to the countries with which Poland had trade deficits in gross terms, deficits tended to be recorded also in VA terms, but they were lower. In the period covered it was true of trade with partners such as China, Russia, South Korea, Taiwan, Finland and Slovenia.

The decomposition of bilateral trade balances by VA content demonstrated that the differences in the value of trade balances in gross terms and in VA terms had been mostly determined by two components: (1) 'multilateral VA net exports to third countries via partner' and (2) 'foreign VA in net exports from other countries than partner'. The value of the former in the Polish trade with the country concerned depended, on the one hand, on the demand of third countries (other than the trading partner) for products containing Polish value added and, on the other hand, on the demand of third countries (other than the trading partner) for products containing VA content from partner country. At the same time, the value of the latter component in the Polish trade with the country concerned depended, on the one hand, on the Polish demand for products imported from the trading partner and containing foreign VA and, on the other hand, on the demand of the trading partner for products brought from Poland and containing foreign VA.

The study confirmed that Poland's participation in global value chains had increased the dependence of the Polish economy on the world economy. For instance, China's shrinking demand for cars produced in Germany from parts supplied by Polish plants will have a downward effect on the trade surplus with Germany in gross terms. Thus, to access benefits derived by Poland from international trade it is recommended to use trade statistics in value added terms.

Although the world input-output tables have many merits, they also involve a number of shortcomings. Firstly, despite the ongoing work on updating the database, the most recent data available are those for 2011. Secondly, it covers 35 economic sectors, including 14 manufacturing industries. It limits the level of detail in trade analyses conducted. Thirdly, the construction of a world input-output table required the adoption of a number of assumptions and the application of many additional estimates, e.g. of differences between the values of exports expressed in FOB prices and those of imports at CIF prices. Further research should include more current trade data. It seems to be especially important to analyse determinants driving Poland's bilateral trade imbalances by sectors, i.e. in the automotive industry. 


\section{REFERENCES}

Ambroziak, Ł. (2015). Znaczenie Niemiec w łańcuchach wartości dodanej państw Grupy Wyszehradzkiej. Miscellanea Oeconomicae, 1, 95-113.

Ambroziak, Ł. (2016a). Polish foreign trade: an analysis using value added statistics. International Business and Global Economy, 35(1), 265-278.

Ambroziak, Ł. (2016b). Value added of exports: the case of the Central and Eastern European Countries. In T. Beridze et al. (Eds.), Proceedings of the International Scientific Conference: Challenges of Globalization in Economics and Business (pp. 48-55). Tbilisi: Publishing House "UNIVERSAL".

Białowąs, T. (2015). Wpływ międzynarodowej fragmentaryzacji procesów produkcji na zmiany strukturalne w handlu krajów Europy Środkowej. Studia i Prace Wydziału Nauk Ekonomicznych i Zarzqdzania, 41(1), 247-261.

Feenstra, R.C. (2010). Offshoring in the global economy: Microeconomic structures and macroeconomic implications. Cambridge, Massachusetts: MIT Press.

Folfas, P. (2016). Światowy i polski handel brutto oraz handel wartością dodaną - analiza porównawcza. International Business and Global Economy, 35(1), 32-43.

Foster-McGregor, N., \& Stehrer, R. (2013). Value added content of trade: A comprehensive approach. Economics Letters, 120, 354-357.

Grossman, G.M., \& Rossi-Hansberg, E. (2008). Trading tasks: A simple theory of offshoring. American Economic Journal, 98(5), 1978-1997.

Johnson, R.C., \& Noguera, G. (2012). Accounting for intermediates: Production sharing and trade in value-added. Journal of International Economics, 86(2), 224-236.

Kaliszuk, E., et al. (2013). Mierzenie wartości dodanej w handlu zagranicznym - nowe koncepcje, metody i wyzwania. Warszawa: IBRKK.

Koopman, R., Powers, W., Wang, Z., \& Wei, S-J. (2011). Give credit to where credit is due: tracing value added in global production chains (NBER Working Papers Series, 16426). Cambridge: National Bureau of Economic Research.

Koopman, R., Wang, Z., \& Wei, S-J. (2014). Tracing Value-Added and Double Counting in Gross Exports. American Economic Review, 104(2).

Nagengast, A.J., \& Stehrer, R. (2014). Collateral imbalances in intra-European trade? Accounting for the differences between gross and value added trade balances (ECB Working Paper Series, 1695). Frankfurt: European Central Bank.

Nagengast, A.J., \& Stehrer, R. (2016), The Great Collapse in Value Added Trade. Review of International Economics, 24(2), 392-421.

Stehrer, R. (2012). Trade in Value Added and the Value Added in Trade (wiiw Working Paper, 81). Vienna: The Vienna Institute for International Economic Study.

Stehrer, R. (2013). Accounting Relations in Bilateral Value Added Trade (wiiw Working Papers, 101). Vienna: The Vienna Institute for International Economic Study.

Stehrer, R., \& Stöllinger, R. (2013) Positioning Austria in the Global Economy: Value Added Trade, International Production Sharing and Global Linkages. FIW-Research Reports, 2.

Stehrer, R., Foster, N., \& de Vries, G. (2012). Value added and Factors in Trade: A comprehensive approach (wiiw Working Paper, 80). Vienna: The Vienna Institute for International Economic Study.

Timmer, M.P., et al. (2015). An Illustrated User Guide to the World Input-Output Database: The Case of Global Automotive Production. Review of International Economics, 23(3), 575-605. 


\section{Author}

\section{Łukasz Ambroziak}

Assistant Professor in the Institute of Agriculture and Food Economics - National Research Institute and Assistant Professor in the Institute for Market, Consumption and Business Cycles Research in Warsaw, Poland. Main scientific interests include foreign trade of the new EU Member States, competitiveness of trade in agri-food products, intra-industry trade, value added in trade and global value chains.

Correspondence to: Łukasz Ambroziak, PhD, Warsaw School of Economics, Collegium of World Economy, Madalińskiego 6/8, building M, 02-513 Warsaw, Poland, e-mail: la28204@sgh.waw.pl

\section{Acknowledgements and Financial Disclosure}

This article is a result of the research project financed by the National Science Centre, decision number: DEC-2014/13/D/HS4/01426.

\section{Copyright and License}

This article is published under the terms of the Creative Commons

Attribution - NoDerivs (CC BY- ND 4.0) License http://creativecommons.org/licenses/by-nd/4.0/

Published by the Centre for Strategic and International Entrepreneurship - Krakow, Poland 
